\title{
Small Farmers Large Field (SFLF): a synchronized collective action model for improving the livelihood of small farmers in India
}

\author{
Sampriti Baruah $^{1} \cdot$ Samarendu Mohanty ${ }^{1}$ (D) Agnes C. Rola ${ }^{2}$
}

Received: 7 January 2021 / Accepted: 22 October 2021 / Published online: 2 December 2021

(c) The Author(s) 2021

\begin{abstract}
This study pilots the collective action model "Small Farmers Large Field (SFLF)" to overcome the disadvantages faced by millions of small and marginal farmers due to diseconomies of scale and lack of bargaining power in the supply chain. This model is participatory and flexible and allows small farmers to benefit from achieving economies of scale by organizing themselves into groups and synchronizing and harmonizing selected operations. It was piloted in two villages of Odisha, an eastern Indian state, with 112 farmers (35 females and 77 males). These farmers organized themselves into groups and synchronized their operations such as nursery bed management, transplanting, and harvesting collectively to achieve economies of scale. The SFLF farmers purchased inputs (seed and fertilizer) and sold paddy as a group to increase their bargaining power in price negotiations. The results from this pilot study showed that the participating farmers almost doubled their profits. Apart from the monetary benefits, these farmers saved time in many joint activities, including input (seed and fertilizer) purchase, paddy sale, and nursery bed management. Other important benefits of the harmonization and synchronization of farming operations were social harmony and sustainability of the farming system.
\end{abstract}

Keywords Synchronized farming $\cdot$ Participatory action research $\cdot$ Small farmers $\cdot$ Doubling income $\cdot$ India

\section{Introduction}

According to the 2015-16 Agricultural Census, 78 percent of Indian farmers are small and marginal with landholding of less than 1 hectare. Since farm income is not enough to support the family, rapid rural outmigration has occurred in search of better economic opportunities in the past two decades (Ali, 2018; Deshingkar, 2010), thus creating labor shortages in agriculture. Rising non-farm opportunities in rural areas are also taking away farmers and agricultural workers and making labor shortages even more acute in India. The supply of agricultural labor and its increasing

Sampriti Baruah

sampriti.baruah@cgiar.org

Samarendu Mohanty

s.mohanty@cgiar.org

Agnes C. Rola

acrola@up.edu.ph

International Potato Center, Lima, Peru

2 University of the Philippines Los, Baños, Los Baños, Philippines wage rate are also affected by social welfare programs such as the Mahatma Gandhi National Rural Employment Guarantee Act (MGNREGA) (FICCI, 2015a). According to this report, rural real wages grew at 6.8 percent per annum from 2007-08 to 2011-12. This is also reinforced by ILO (2018): the real wages of casual agricultural laborers in India increased by 6.6 percent annually from 2004-05 to 2011-12 vis-à-vis the 2.2 percent annual increase from 1993-94 to 2004-05.

Apart from labor scarcity and rapidly rising wage rates, small and marginal farmers are already at a disadvantage because of the size of their operations. They usually do not have the scale to mechanize some of their labor-intensive farm operations such as planting and harvesting, they have high transaction costs in both input and output markets, and they are difficult to reach with the knowledge needed to efficiently fare in farming (Timmer, 2002). This small size is even becoming smaller with a decline in average landholding from 2.3 hectares in 1970-71 to 1.15 hectares in 2010-11, and further declining to 1.08 hectares in 2015-16 (various issues of Agricultural Census). More importantly, 68.45 percent of the landholdings belong to marginal farmers with less than 1 hectare (GOI, Agricultural Census Report, 2019). 
The challenge lies in integrating small farms in the everdynamic process of agricultural transformation.

The declining farm size makes mechanization even more nonviable, which plays a key role in improving agricultural production and productivity and decreasing cost. According to Singh et al. (2014), Indian states with a greater availability of improved equipment and mechanical power show higher productivity than other states. But, availing of the benefits of mechanization is a big challenge when landholdings are small and fragmented and economic resources are limited. Mechanizing small and non-contiguous groups of small farms is against economies of scale, especially for operations such as land preparation and harvesting (Mehta et al., 2019). With continued shrinkage in average farm size, more farms will fall into an adverse category, thereby making individual ownership of agricultural machinery progressively more uneconomical. Also, farm machinery is capital intensive and a majority of Indian farmers are not able to acquire these assets because of a shortage of capital. The unwillingness of commercial banks to finance farm equipment is another big obstacle to increasing mechanization. Also, after-sales service is a challenge: because of the remoteness of rural areas, machine maintenance centers are not easily available and accessible in most villages (FICCI, 2015b).

In addition to diseconomies of scale, small and marginal farmers lack access to both input and output markets. Better access to markets can result in expanded production and the adoption of productivity-enhancing technologies (Al-Hassan et al., 2006). In the absence of market linkages, farmers must depend upon local traders and middlemen for the disposal of their farm produce, which is then sold at throwaway prices (Murthy et al., 2007). Thus, inaccessibility to markets lowers farmers' profitability and disincentivizes production and quality control goals, thereby leading to an adverse effect on both efficiency and equity (Bardhan, 1989; Clay, 2004).

The constraints faced by small and marginal farmers have been identified as the key bottleneck by several recent policy papers, including Gulati and Saini (2016), Chand (2017), and Singh (2018), in improving farmers' income. Apart from focusing on traditional strategies such as technology upgradation for improving crop yield, improved production practices to decrease cost and improve sustainability, diversification toward high-value crops, infrastructure development, market linkages, a conducive policy environment, and proper institutional mechanisms, these studies have pointed out the need for collective action to minimize the disadvantages of scale effects on small and marginal farmers and to garner bargaining power in input and output markets.

Farmer Producer Organizations (FPOs) and Farmer Producer Companies (FPCs) are examples of recent government initiatives to improve farmers' bargaining power by pooling resources and linking them to the market. But, FPOs/FPCs, which are a hybrid between a cooperative and a private company, are also struggling from stiff market competition and the lack of professional and qualified managers to manage them (Bishnoi \& Kumari, 2020). The FPOs/FPCs are required to be efficiently managed by an experienced, trained, and professionally qualified CEO and other personnel under the supervision and control of a democratically elected board of directors. However, a study conducted by NABARD (2019) finds that such a trained workforce is not easily available in rural areas to manage FPOs professionally. Also, the FPOs are often found to be too financially weak to deliver products and services to their members and build confidence due to the lack of access to affordable credit for want of collateral and credit history.

In this study, a participatory collective action model, Small Farmers Large Field (SFLF), was piloted to address the key challenges faced by millions of small and marginal farmers in India. The SFLF concept was adapted from the Large Field Model (LFM) of Vietnam. The term "Large Field Model" was first introduced by the Ministry of Agriculture and Rural Development (MARD) in a workshop organized in the Mekong River Delta on March 26, 2011 (Thang et al., 2017). The LFM program gained immense popularity, with area increasing from just 8 hectares in 2011 to 196,000 hectares in 2015 (Mohanty et al., 2018). The LFM development programs also attracted the participation of large rice production companies and farmer cooperatives. The major companies included Loc Troi group and Vinafood 2. The Loc Troi group in 2014 facilitated the establishment of 471 farmers' cooperation groups, with a total production area of 40,000 hectares. According to Dang (2016), technical support was also provided to farmers by these companies and this helped to increase their profits by VND 2.5-4.0 million per hectare (USD 110-180 per hectare). In Vietnam, the LFM has also contributed to improving the quality of rice production for export. As farmers followed standardized crop schedules, these companies could maintain harvesting dates in their production zones in sequence, thereby optimizing capital investment, labor supply, and storage (Thang et al., 2017). Over the years, different forms of the LFM have been operational in Vietnam (Ba et al., 2019). Some of them are very formal, with actual land pooling from farmers to set up a company, operating like a private business with farmers as shareholders, and others operating as an informal entity with synchronization and harmonization of only selected operations for improving efficiency and lowering cost (Mohanty et al., 2018).

The informal LFM with synchronization and harmonization of only selected operations was customized to work in Indian situations and is called the "Small Farmers Large Field (SFLF)" model.

This model is founded upon the principle of aggregating farmers to achieve bargaining power by strengthening backward and forward integration along the supply chain. Thus, 


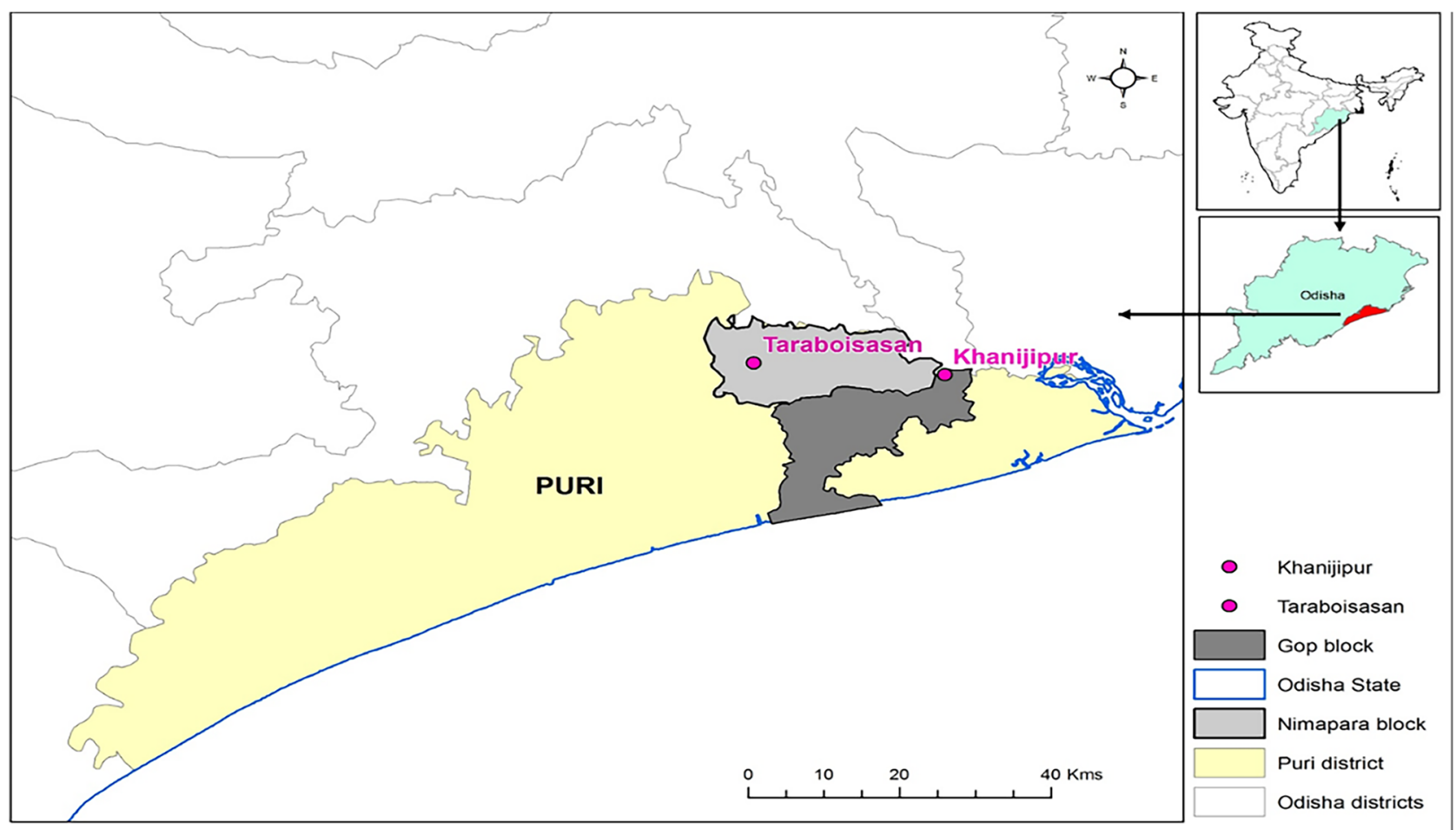

Fig. 1 SFLF pilot sites

under this model, the participating farmers organize themselves into groups to purchase inputs, contract a machine service provider for transplanting and harvesting, and synchronize their operations by adopting a single variety, establishing a group nursery, and transplanting and harvesting around the same time, thus essentially converting their small landholdings into a large field or patch. This approach enables small farmers to cut cost by bulk purchases, improve efficiency by synchronizing operations, and improve quality by having a single variety of certified seed and improved production practices. Each participating farmer collectively commits as a group to follow the same cropping calendar, production practices, and product selling plan. Timelines need to be managed as a group so that, during mechanized steps such as transplanting and harvesting, a single machine could be maneuvered in the entire patch. Within a patch, which is formed by individually owned contiguous plots, every farmer is responsible for cultivating his/her own plot. Also, timely accomplishment of farming activities and arranging the investment for one's own plot are an individual's responsibility and thus there is no profit sharing for a patch, but each participating farmer earns individual profit from his/her own plot.

The remainder of this article is organized as follows. First is a description of the pilot sites. Following this are the methodology and data collection. The final section includes results and policy reforms needed for scaling up of the SFLF model.

\section{Pilot sites}

The SFLF model was piloted in two locations (Taraboisasan Village and Khanizpur Pradhansahi hamlet) in the state of Odisha (Fig. 1). These locations were selected for the SFLF pilot experiment because of their proximity to the state capital, Bhubaneswar, and to take advantage of the technical support available in the area by the ongoing IRRI (International Rice Research Institute)-led technology intervention projects such as Stress-Tolerant Rice for Africa and South Asia (STRASA) and Cereal Systems Initiative for South Asia (CSISA).

Taraboisasan Village is in Nimapara block of Puri District of Odisha (Fig. 1). The total geographic area of the village is 427 acres, out of which 318 acres are agricultural land. The village has six different hamlets (Sahis), organized around caste categorizations. Other Backward Class $(\mathrm{OBC})^{1}$ is the dominant group in the village (70 percent) along with Schedule Caste (20 percent) and General Class (10 percent). Agriculture is the main occupation practiced in this village. Taraboisasan residents mainly cultivate rice

\footnotetext{
${ }_{1}$ Other Backward Class (OBC) is a collective term used by the Government of India to classify castes that are educationally or socially disadvantaged. It is one of several official classifications of the population of India, along with General Class, Scheduled Castes (SCs), and Scheduled Tribes (STs).
} 
in both the wet (kharif) and dry (rabi) seasons, along with some pulses in the dry season, managing their water requirements in both seasons. Seventy percent of the total farming households are small farmers, with average landholding size of 1 acre. In 2011, the literacy rate of Taraboisasan Village was 90 percent (the male literacy rate was 96 percent and the female literacy rate was 84 percent). In the wet season, the water requirement is mostly taken care of by the southwest monsoons (occurring from June to September) and in the dry season farmers source groundwater from the 10 tube wells in the village. Ninety-five percent of the farmers in Taraboisasan are small and marginal and none of them own any individual tube well on their own plots. Six of the individually owned tube wells in the village are owned by the 5 percent bigger farmers. The small and marginal farmers manage the irrigation requirements of the dry season mostly with the four community-owned tube wells or by borrowing water access from the bigger farmers by paying a small service charge in cash or by working in their fields as farm labor.

Khanizpur Pradhansahi is a small hamlet in Gop block of Puri District of Odisha (Fig. 1), inhabited by just 45 households, 85 percent of which are OBC, 9 percent are SC, and 6 percent are General Class. Agriculture in Khanizpur is mostly managed and done by the women, as all the men venture out of the hamlet to work as laborers in factories, at construction sites, and in the nearby markets. Ninety percent of the households do not own any land; therefore, they lease/rent land every season to practice agriculture as tenants. They practice only one season of rainfed agriculture in the wet season because they have no water resources in their hamlet to manage the dry-season irrigation requirements. As all farmers are tenant farmers, their operating plots are not always close to their hamlet and the landowners of the plots do not invest in installing any irrigation facility on the plots put on rent Also, in the government database, Khanizpur and the hamlets surrounding the village do not show any record of owning any agricultural land and thus this has not been covered under any of the state government's irrigation schemes. Most households in the hamlet prefer to carry out paddy cultivation in the wet season, although some also engage in rainfed cash crop production such as cucumber, ridge gourd, snake gourd, okra, etc.

\section{Methodology and data collection}

This study uses an embedded mixed method (EMM) research design. Mixed methods research is the type of research in which a researcher combines elements of both qualitative and quantitative research approaches (e.g., use of qualitative and quantitative viewpoints, data collection, analysis, inference techniques) for a better understanding of research problems and corroboration (Schoonenboom \& Johnson, 2017). An embedded mixed method design occurs when, in a traditional qualitative or quantitative design, a strand of the other type is added to enhance the overall design (Creswell \& Clark, 2011). According to Schoonenboom and Johnson (2017), one can consider mixing with any or all of the following research components: purposes, research questions, theoretical drive, methods, methodology, paradigm, data, analysis, and results.

This study is structured and organized on the paradigm of pragmatism. It believes that "actions cannot be separated from the situations and contexts in which they occur" (Morgan, 2014). It believes in real-world practice, action, and change. The underpinning rule of thumb of pragmatism is "what works" and the use of all approaches available to understand the problem (Rossman \& Wilson, 1985); as such, it embraces a plurality of methods. It is based on the proposition that researchers should use the philosophical and/or methodological approach that works best for the particular research problem that is being investigated (Tashakkori \& Teddlie, 1998), thus paving the way for mixed methods research.

Real-world practice, action, and sustainable change would emphasize the agency of those involved as a goal and building their capacity to bring about social change. It requires viewing communities as dynamic promoters of social transformation, actively participating in altering their lives and the lives of others (Narain \& Bhal, 2016). In the context of agriculture, this would mean farmer participation in the generation, testing, and evaluation of technology and methods to increase or promote sustainable agricultural production at the community level. This process is usually conducted in farmers' fields through joint efforts between agricultural scientists and farmers (Chambers, 1994). The idea is to generate or propagate technologies that fulfill the production needs of small farmers through a bottom-up approach. This study clearly identifies community participation to be the key to ensuring sustainable changes at the grass-roots level, and thus decided to adopt a participatory action research (PAR) approach. PAR is a subset of action research, which is the "systematic collection and analysis of data for the purpose of taking action and making change" by generating practical knowledge (Gillis \& Jackson, 2002). PAR is an approach within qualitative research methodology. Epistemologically, it rests on the premise that reality is interconnected, dynamic, and multivariate. It is contextspecific and often targets the needs of a group. PAR is an iterative cycle of research, action, and reflection, which uses a range of different methods, both qualitative and quantitative. To understand the multivariate characteristic and outcome of an SFLF pilot implemented with a PAR approach, this study uses an EMM research design to mix both qualitative and quantitative datasets at the design level, at which a 
few sets of quantitative close-ended questions were embedded within a larger qualitative methodology and procedure. In the QUAL + quan design of this study, the qualitative methodology or dataset assumes the primary role while the quantitative dataset becomes secondary or supportive. The mixing of strands in a research study can be emergent or fixed (Creswell and Clark, 2011); this study's design falls in the fixed category. Fixed approaches are predetermined and planned at the start of the research process, and the procedures are implemented as planned.

The embedded MMR design for this study is represented in Fig. 2:

a. The first box (QUAL before intervention) represents the initial qualitative data gathering done as the first step of this action research study. This data which was collected between December 2015 to February 2016 in the first season, in June 2016 for the second season and in November 2017 in the third season entails: initial observations, key informant discussions on the prospective plan of the SFLF model and detailed group discussions on the prevailing production practices of the participating farmers. b. The second box (quan premeasure) represents quantitative baseline data collection on the prevailing practices and their cost. This data was collected between June and August 2016 in the first season, between June and July 2017 in the second season and in May 2017 for the third season. This was done using a detailed survey questionnaire and a trained enumerator.

c. During the intervention period of the three seasons represented by the lowermost box (QUAL during intervention), regular qualitative data was collected to record the various emergent issues and situations. This was collected between December 2016 to April 2017 in the first season, between August to October 2017 in the second season and between December 2017 to April 2018 in the third season.

d. Post-intervention, a second round of quantitative data gathering was carried out after completion of harvest and sale of produce (this data was collected in May 2017 for the first season; October 2018 for the second season and May 2018 for the third season) to calculate the cost and returns of the SFLF intervention, again using a detailed structured survey questionnaire. This is represented by the third box (quan postmeasure) in Fig. 2.

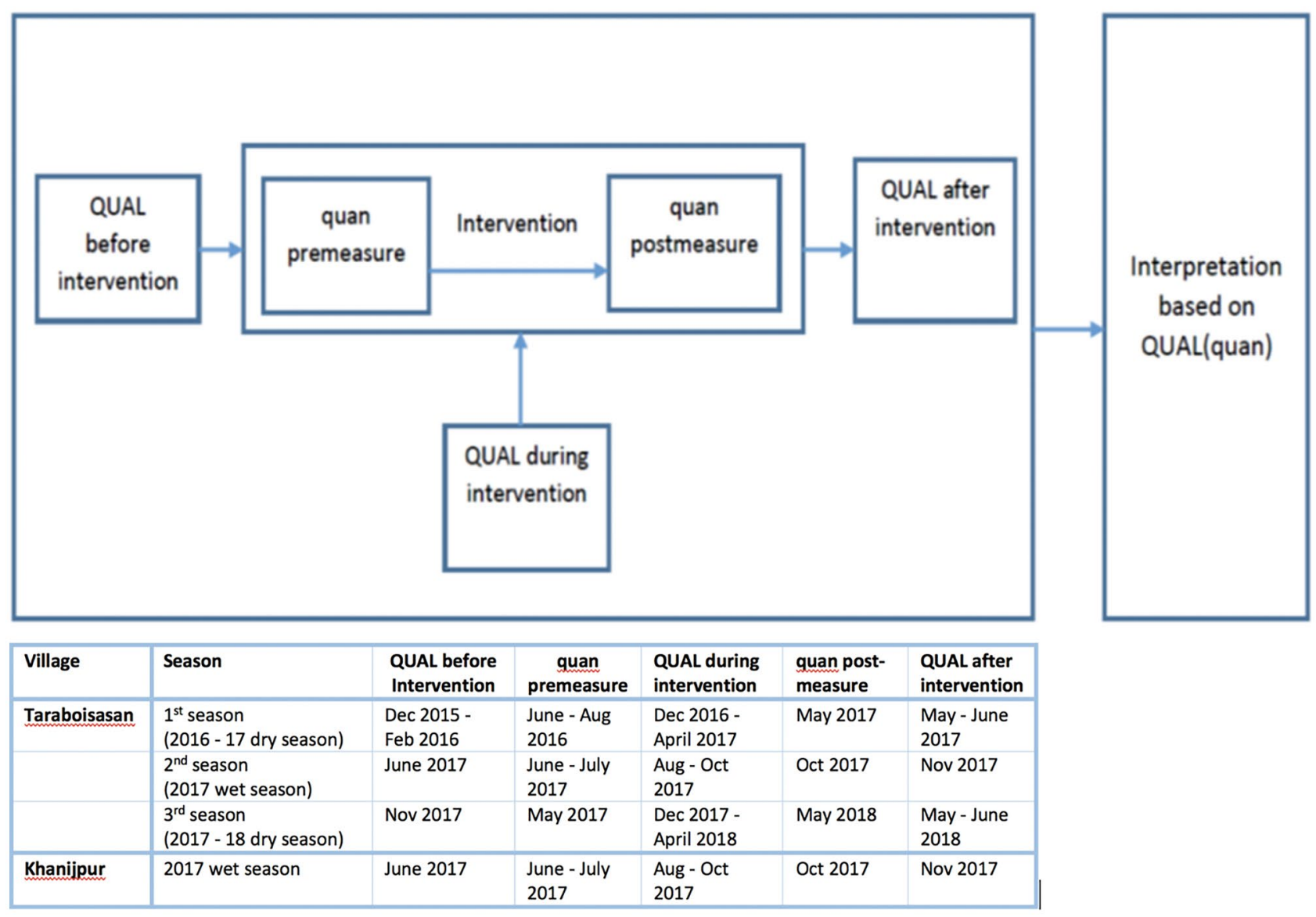

Fig. 2 Embedded mixed method design adopted by SFLF pilot 
e. A final round of qualitative data collection was done after completion of all activities of a crop season to contextualize the achieved outputs. This is represented in the fourth box (QUAL after intervention) in Fig. 2. This was done between May and June 2017 in the first season, in November 2017 for the second season and between May and June 2018 in the third season.

Quantitative data collection was done from the whole population of participating farmers, which is 54 (from Taraboisasan Village) in the first season, 112 in the second season ( 77 from Taraboisasan and 35 from Khanizpur hamlet), and 55 (from Taraboisasan) in the third season. Quantitative data were required in this primarily qualitative research methodology to mainly calculate the cost and the net profit of the model. The baseline data was collected using a recall approach whereas during interventions the data was collected on a real time basis throughout the seasons.

Qualitative data collection was done using maximum variant purposive sampling of the participating farmer population from both study sites. The methods employed for the qualitative data collection were unstructured interviews, focus groups, in-depth key informant interviews, and participant observation.

The PAR approach provided the study with an opportunity to engage with the community in the development of the SFLF pilot experiment, thus allowing for clarifications and reflections that improved the researchers' understanding of local situations and problems to shape the strategies rather than prematurely introducing external ideas from Vietnam. Active participation helped to take the learning process of the program beyond reflection and toward capacity building, which built the knowledge and skills for the participating farmers to act in their community as leaders or agents of change.

\section{Results}

\subsection{SFLF participation and implementation}

The SFLF model was first piloted in the 2016-17 dry season in Taraboisasan Village. In the first season, 54 farmers participated by allocating 90 acres (which is percent of the total land possessed by these 54 farmers as both owner and tenant) of their individual plots. These 90 acres were organized in the village as three big patches of land, achieved by integrating 130 individual plots. So, this was like operating in three big fields instead of 130 small individual plots.

A women's self-help group (SHG) leader from a small hamlet called Khanizpur Pradhansahi, located $25 \mathrm{~km}$ away from Taraboisasan, had visited a relative living in
Taraboisasan Village. She requested the farmer she was visiting to introduce her to the study team and further requested the study team to organize a learning and exposure trip for a few women SHG members of her hamlet. Upon seeing and understanding the model, the Khanizpur farmers informed that they were interested in trying out this model in their own hamlet in the wet season. With that, 35 female tenant farmers from Khanizpur hamlet joined the SFLF pilot in the wet season of 2017 . They allocated 38 acres (52 percent of the total land rented by these 35 farmers for that season) by putting together 111 individual plots organized in three big patches. In addition to Khanizpur, in Taraboisasan the farmers continued with the SFLF model of collective farming in the wet season of 2017 with a larger group. The number of participating farmers increased from 54 to 77 with the allocation of 171 acres of land (which is 91 percent of the total land possessed). These 171 acres were again organized in three big patches, achieved by integrating 237 individual plots.

The third season of the SFLF pilot was the dry season of 2017-18. In this season, the farmers of Taraboisasan Village continued with SFLF farming, whereas Khanizpur farmers could not continue in the dry season because of the lack of irrigation. In this season, the study team decided to limit its involvement and acted as only observers and advisors to check whether the farmers were really convinced about the viability of the model and would like to continue operating under it on their own initiative. A total of 55 farmers from Taraboisasan came together again, putting together 102 acres of land (which is 84 percent of the total land possessed).

In each village, the participating farmers selected an eight-member committee to take on the role of facilitator between them and the study team. They first nominated a few names from among themselves and then elected the final eight by casting votes. The committee facilitated discussions among the participating farmers and acted as community mobilizers. On learning that growing a single variety would benefit from economies of scale with uniform grain quality and no varietal mix, the farmers unanimously chose BINA Dhan-11, a new flood-tolerant rice variety from Bangladesh that was released in Odisha for the two dry seasons, and Swarna-Sub1, another flood-tolerant variety for the wet season. All seeds were procured from a single certified seed producer. The farmers revealed that the dry season witnesses strong winds and rain toward the end of the season (April/ May). In the previous season, they had witnessed in a demonstration/trial plot laid out by the CSISA project of a nearby village that BINA Dhan-11 showed good stem strength and could withstand the windspeed and resulted in a good rate of production. Variety Swarna-Sub1 was selected for the wet season as it showcased effective flood tolerance in the early stage of the crop and, as few farmers in Taraboisasan Village had tried this variety in the previous season, all the remaining farmers were impressed by its performance. 
The first synchronized and collective activity to be undertaken was nursery management. A field extension specialist from the study team monitored and convinced the participating farmers to prepare nursery beds in groups. This was organized in patches, with the largest patch serving for approximately 30 acres in the first and second season pilot in Taraboisasan. It took some effort to assemble the farmers into groups based on their field location, tube well location, and relationship with their fellow farmers. With successful mat-type nurseries prepared, the next big task at hand was to organize land preparation and mechanical transplanting in the patches. The land preparation was managed through tube well irrigation in the dry season. All the participating farmers used tractors (both hired and own) and puddlers to complete land preparation. The uprooting of seedlings from the nursery was done by the farmers using a technically guided method to fit the seedlings properly in the transplanting machine. All the farmers carried their seedlings from the nursery bed site to their own plots manually. Mechanized transplanting took place after 23 days of nursery raising. Transplanting was implemented using mechanical transplanters. Inputs such as fertilizer, pesticide, and herbicide were procured from the Indian Farmers' Fertilizer Cooperative Limited (IFFCO). Before the harvest, few local millers were invited to visit the SFLF site at both location. In response, they assured that they would be interested in purchasing all the harvest at a price higher than the market price. The eight-member committee of each location picked one miller based on offering price and reputation. Harvesting was conducted in the patches using combine harvesters.

\subsection{Group nursery development}

Nursery beds for rice seedlings were developed in groups of six to seven farmers. This helped to maintain uniformity in seedling growth, ensured proper care and maintenance, and subsequently ensured transplanting on time. This saved both money and time. If each individual farmer raised his/ her own separate and single nursery, this would incur more cost in land preparation, as a tractor would be made to run in an entire plot or a larger area and only a little patch would be used for the nursery bed. Therefore, farmers revealed that it was useful to raise multiple beds in the same plot and share the cost of land preparation. In groups, the farmers took turns taking care of their seedlings. One person is enough to water an entire plot and this saved farmers' time. Also, it is easier to water bigger patches laid out next to each other in a single plot without wasting water in transportation from one plot/field to another. When the seedlings are ready, transportation for transplanting is also carried out as a group activity with exchange labor provided to each other, which further saves both time and money. The farmers believed that the seedlings were of better quality because of group learning.

\subsection{Mechanization}

The study team listed each step of paddy production for which mechanization was possible and also calculated the change in cost of cultivation if mechanization was adopted as a group. The participating farmers decided to use a tractor and power tiller for land preparation, a mechanical transplanter for transplanting the mat nursery and a combine harvester for harvesting, reaping, threshing, and winnowing.

Taraboisasan had only five four-wheel tractors in the village, nine two-wheel power tillers, and three threshers, owned by a few of the better-off farmer entrepreneurs, who also acted as service providers for the other farmers. Nobody in the village owned the big machines required in rice farming such as a transplanter and combine harvester. The study helped the participating farmers establish contact with service providers for a mechanical transplanter and combine harvester from outside the village as well as from outside the district, as none was available within the district. A meeting was organized between the service provider and the eightmember committee representing the participating farmers. Since the service provider of the machines received a group contract from all participating farmers, organized under three big patches and not small fragmented individual plots, the provider agreed to come to Taraboisasan and offered discounted rates. For harvesting in the two dry seasons, both wheel-operated and chain-operated harvesters were hired directly from the district-level service provider without the involvement of village-level middlemen. But, in the wet season, only chain-operated combine harvesters were used, as wheel-operated combine harvesters are difficult to use when the soil is slushy due to rain.

Unlike Taraboisasan, Khanizpur farmers had almost nil or very little equipment and few machines at their disposal except for a few handheld tools such as a hoe and sickle. Since the topographical features of the land allocated under the SFLF model were divergent with 5 percent upland, 65 percent medium/semi-medium land, and about 30 percent lowland, it was not feasible to operate a mechanical transplanter or combine harvester on all land types. Therefore, the participating farmers decided that land preparation would be done using a tractor and tractor-attached puddler. Although mechanical transplanting could have been used on the 65-percent medium and semi-medium land, only 15 percent of the farmers operating on the medium and semimedium land could convince their landowners to allow them to use a mechanical transplanter. The rest opted for manual transplanting with proper crop-to-crop distancing. 
Harvesting was also done manually ${ }^{2}$ as the farmers needed rice straw for their thatched roof, fuel, and animal feed. The combine harvester would have cut the straw residue into very small pieces and scattered the cut pieces all over the field. The study team thus facilitated establishing contact with service providers for tractors and mechanical transplanters from outside the hamlet at a discounted price.

\subsection{Better access to inputs}

During the pre-intervention FGDs conducted to understand the existing practices and gaps in Taraboisasan's rice farming system, the participants revealed that in the previous seasons they faced difficulties in buying urea, diammonium phosphate (DAP), and potash because of the high price and untimely availability. The fertilizer reached the local dealer after passing through a range of actors/stakeholders in the supply chain, including company-run wholesale outlets, wholesale distributors at the district level, and small dealers at the block level, thus making it very expensive for the farmers. The women farmers from Khanizpur hamlet shared that, in most seasons, fertilizer was never available on time in their village input shop. They would sometimes request their husbands to source it from the bigger market of the block, ${ }^{3}$ but it would still be unavailable on time.

Under the SFLF model, the participating farmers were directly connected with the company-run wholesale outlet of IFFCO in Bhubaneshwar (the state capital of Odisha). The study team requested IFFCO to provide the farmers with the wholesale rate as the participating farmers placed a single bulk order for 90 acres in the first season, for 172 acres in the second season, and for 102 acres in the third season. Since this was a group bulk purchase, it was possible to convince IFFCO to supply inputs at the doorstep and at a price that was 15 percent lower than the prevailing retail price. The cost of fertilizer was calculated based on size of the plot of each farmer with respect to the requirement. Funds were collected from each participating farmer by the eight-member

\footnotetext{
$\overline{2}$ In manual harvesting, the crop is cut by manual labor and placed in bundles on the field surface. The bundles are then placed in a heap in the corner of the field. Threshing (removing the grain from the rest of the plant, including the stalk) is done by a stationary thresher that is brought to the field. As a result of the threshing operation, the straw is in a heap near the outlet of the thresher. In the manual grain harvesting system, straw can be collected at a central location, where it is packed in bales.

The combine harvester cuts the crop while the machine moves through the field, threshes the crop, and scatters the straw sideways or behind the threshing mechanisms. As a result, the straw is left in a windrow behind the combine, and the windrows are spread throughout the field.

${ }^{3}$ Block is a district sub-division in India. For planning purposes, a district is divided into four levels: tehsils, blocks, gram panchayats, and villages.
}

committee and a bulk order was placed with IFFCO for supply after conducting a comparative cost analysis of fertilizer market prices. In the first season, a total of $4399 \mathrm{~kg}$ of DAP, $3989 \mathrm{~kg}$ of potash, $4811 \mathrm{~kg}$ of urea, and $10 \mathrm{~L}$ of herbicide were procured from IFFCO. In the second season, a total of $10,469 \mathrm{~kg}$ of DAP, $9476 \mathrm{~kg}$ of potash, $10,469 \mathrm{~kg}$ of urea, and $30 \mathrm{~L}$ of herbicide were procured from IFFCO for both villages. In the third season, a total of $4150 \mathrm{~kg}$ of DAP, $2000 \mathrm{~kg}$ of potash, $3000 \mathrm{~kg}$ of urea, and $10 \mathrm{~L}$ of herbicide were procured from IFFCO.

The use of good-quality seeds is one of the most important factors in increasing agricultural production in any farming system. The participating farmers of both pilot sites benefited by becoming connected to a reputed seed dealer. The seed dealer obliged the delivery of the seed directly to their village as it was a bulk order, almost appearing like an order by a single entity but in reality it was a combined order by 54 farmers in the first season, by 112 farmers (put together at both locations) in the second season, and by 55 farmers in the third season. A total of 2.5 tons of certified seed of high-yielding variety BINA Dhan-11 were procured by the farmers in the first season and around 10.5 tons of certified seed of high-yielding submergence-tolerant variety Swarna-Sub1 were procured in the second season. One of the seed sources regularly accessed by the Taraboisasan farmers before the study intervention was the district cooperative society. One acre of land requires $20 \mathrm{~kg}$ of seeds (as per the seed rate practiced in Taraboisasan). And the cooperative society sells only $20-\mathrm{kg}$ or $25-\mathrm{kg}$ packs. A few of the farmers own plots as small as 0.2 acre. The seed requirement for 0.2 acre would be only 4 to $5 \mathrm{~kg}$ and that would require these farmers to be dependent on the bigger farmers for collaboration or on the village seed dealers, who charged a higher price and could not provide any quality or germination assurance.

\subsection{Better market linkage}

Before the SFLF pilot, the farmers of Taraboisasan sold their produce by only two means: (1) to the village middlemen or traders, at a price decided by them, or (2) at the "kisan mandi." ${ }^{4}$ The mandi accepts paddy from the farmers

\footnotetext{
4 The mandi is basically a government-regulated wholesale market where farmers sell their produce to buyers through an auction. It is operated as per the regulations of the Agricultural Produce Market Committee (APMC) act. Essentially, under this act, the state government divides the state geographically and forms APMCs, which set up and manage mandis in the designated geographic area. The auction is facilitated by the commission agents or middlemen at the mandi, who hold a license and are allotted a shop in the market. APMCs also "notify" certain commodities to be sold at the mandi. The notified commodities can be sold only through the mandi in its geography. The farmers cannot sell these commodities directly to the buyers.
} 
depending on their family size (only 18 quintals per registered acre and deducting 3 quintals for each family member declared in the registration). In addition, farmers are required to pay a labor charge for loading and unloading of their produce.

The farmers of Khanizpur had only one way of selling their small produce without any bargaining power, which was to the village middlemen. As tenant farmers, 50 percent of their produce had to be given away to their landowners and, from the remaining 50 percent, they would save some for self-consumption and sell the surplus amount. In the previous years, in their individual mode of dealing with village traders for a very small quantity of production, effective price negotiation was never possible. Also, these farmers couldn't access the kisan mandi because the land title was not in their name.

The study facilitated the farmers becoming connected to the rice millers. Before the harvest, the study team contacted a few local millers and invited them to visit the SFLF site. In response, the millers assured that they would be interested in buying all the paddy at a higher than market price. They were willing to pay more because they would be able to procure a large quantity of paddy from each location with no varietal mix and with uniform grain quality.

\subsection{Land preparation and water management}

When farmers practiced the individual mode of farming, every field needed water at a different time and the farmers faced difficulty in coordinating the irrigation schedule. The situation became complex when one plot needed irrigation and the adjacent plot belonging to another farmer had a mature standing crop in it and didn't require irrigation. This created tension among the farmers as the water seeped into the field with a mature crop. In the previous years, farmers with bore wells did not allow adjoining plot farmers to irrigate through the channels of their own plot.

After land preparation and before transplanting, the fields are left for 2 days without any activity so that existing water gets drained out. As shown in Fig. 3, if plot 1 (left plot in Fig. 3) has completed its land preparation and is in its 2 days of water draining stage and plot 2 (middle plot) is in its land preparation stage when water is used, then water seepage or spilling into plot 1 , which is in its drying stage, would always be a situation of conflict between farmers. Again, when the crops are in their growing stage, they must be watered repeatedly and there is sure to be some spilling over to the adjacent plots. Therefore, with a synchronized farming model, participating farmers were able to handle all these problems effectively and avoid water wastage.

\subsection{Social network building and support of exchange labor}

Every farmer participating in this study cultivated his/her own plot but needed to synchronize every farming activity with the fellow farmers from the same patch. A timeline needed to be managed so that, during mechanized steps such as transplanting and harvesting, a single machine could be maneuvered in the entire patch. In doing so, farmers of the same patch supported each other by providing exchange labor in each other's plot. Before engaging in the SFLF model, the farmers of Taraboisasan Village used both hired labor and family labor to complete the various labor-intensive stages of production. But all farmers could not afford to hire labor. For them, it took a long time to complete the laborintensive stages of farming. After participating in the SFLF pilot, the farmers developed a feeling of group camaraderie, which resulted in helping each other with exchange labor. The intake of hired labor decreased by 90 percent for all the study participants. Inputs such as seed and fertilizer had to be bought at the same time and thus the farmers also helped each other with required finances, if anyone from the same group or patch fell short. They also supported each other's farm responsibilities in times of an emergency, such as falling ill or having an accident. For example, one participating farmer in the first season who became injured while removing mat nursery beds for transplanting was supported by other farmers in completing his transplanting.

\subsection{Cost-return analysis}

Tables 1 and 2 present a cost-return analysis of Taraboisasan and Khanizpur farmers both with and without SFLF in 2016 prices. As shown in Table 1, the average per acre profit of Taraboisasan farmers nearly doubled in real terms because of SFLF group farming from INR 12,130 in 2016 to INR 24,830 in the 2017 dry season. In the first season in Taraboisasan, transplanting was implemented together in the three big patches over 3 consecutive days using eight mechanical transplanters. The service provider agreed to charge an average of INR 1,839 per acre vis-à-vis the INR 2,100 per acre in the previous season. Harvesting was conducted in the three patches at the same time using three
Fig. 3 Illustration of irrigation channels in rice fields

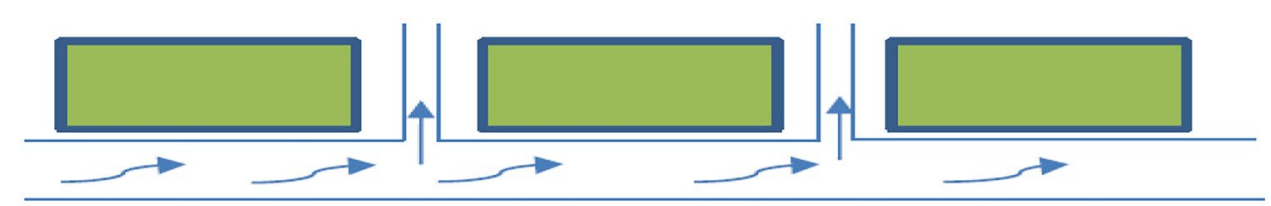


Table 1 Real Cost and Returns, Taraboisasan (in 2016 price)

\begin{tabular}{|c|c|c|c|c|c|}
\hline Item & $\begin{array}{l}\text { Dry (Rabi) } 2016 \\
\text { Baseline }\end{array}$ & $\begin{array}{l}\text { Dry (Rabi) } 2017 \\
\text { SFLF }\end{array}$ & $\begin{array}{l}\text { Dry (Rabi) } 2017 \\
\text { SFLF }\end{array}$ & $\begin{array}{l}\text { Wet (Kharif) } 2016 \\
\text { Baseline }\end{array}$ & $\begin{array}{l}\text { Wet (Kharif) } 2017 \\
\text { SFLF }\end{array}$ \\
\hline No. of farmers & & 54 & 77 & & 35 \\
\hline Yield (tons/acre) & 2.2 & 2.8 & 2.5 & 1.8 & 2.2 \\
\hline Price (INR/quintal) & 1250 & 1336 & 1304 & 1350 & 1452 \\
\hline Gross income (INR/acre) & 27,500 & 37,394 & 32,587 & 24,300 & 31,936 \\
\hline \multicolumn{6}{|c|}{ COST and Return per Acre (in 2016 price) } \\
\hline Seed & 320 & 310 & 298 & 500 & 387 \\
\hline Seed treatment & 40 & 39 & 37 & 40 & 39 \\
\hline Nursery bed preparation & 400 & 194 & 279 & 340 & 242 \\
\hline Land preparation & 2400 & 2129 & 1955 & 2400 & 2129 \\
\hline Irrigation & 2000 & 1936 & 1862 & 0 & 0 \\
\hline Crop establishment & 2100 & 1839 & 1397 & 1800 & 1548 \\
\hline Gap filling & 400 & 387 & 372 & 200 & 194 \\
\hline Manual + chemical weeding & 1050 & 765 & 993 & 1321 & 873 \\
\hline Fertilizer application & 2500 & 2661 & 2551 & 2803 & 2141 \\
\hline Pesticide & 1400 & 842 & 1303 & 1648 & 1496 \\
\hline Harvesting (machine hiring cost) & 2500 & 1936 & 2514 & 3000 & 2419 \\
\hline $\begin{array}{l}\text { Cost incurred on storage of produce } \\
\text { until sold }\end{array}$ & 260 & 281 & 279 & 300 & 290 \\
\hline Total Cost per Acre & 15,370 & 13,319 & 13,840 & 14,352 & 11,758 \\
\hline Net Return per Acare & 12,130 & 24,075 & 18,747 & 9948 & 20,178 \\
\hline $\begin{array}{l}\text { T statistics } \\
\text { ( } \mathrm{p} \text { value) }\end{array}$ & & $\begin{array}{l}9.08 \\
(<0.0001)\end{array}$ & $\begin{array}{l}8.58 \\
(<0.0001)\end{array}$ & & $\begin{array}{l}15.04 \\
(<0.0001)\end{array}$ \\
\hline
\end{tabular}

combine harvesters over 6 days. The provider of the combine harvester agreed to charge INR 1,936 per acre (in 2016 prices) vis-à-vis the INR 2,500 per acre paid by the SFLF farmers in the previous season. Also, the price received by the SFLF farmers for their paddy was INR 1,000 per ton higher than the prevailing market price at that time.

At the end of the 2017 wet season, the average per acre profit was estimated to be INR 20,178 vis-à-vis INR 9,948 in the previous wet (2016) season. The increase in profitability was attributed to the cost reduction in farm operations due to harmonization and synchronization and higher gross revenue due to greater bargaining power for input and output markets and higher yield due to better seed and improved crop management practices.

At the end of the third season in Taraboisasan, in the 2018 dry season, the average per acre profit was estimated to be INR 18,745 . The net profit per acre was satisfactory for the farmers when they compared this with what they used to earn without practicing the SFLF model. But, for the study's analysis, the net profit per acre for the third season was less than that for the previous dry season of 2017 , which was the first SFLF pilot. The farmers attributed this decrease to the decrease in yield from 2.8 to 2.5 tons per acre. The farmers explained that the main reason behind the decrease in yield rate was a failure to procure certified seeds of variety BINA Dhan-11 from a single reliable source. As they were practicing the SFLF model on their own, for the first time, they missed placing the seed order on time. For all three SFLF seasons, the $p$ values of close to zero for the twosample t-test of net income with their respective baseline season suggest the rejection of the null hypothesis of equal net income at 1 percent or higher significance level.

For Khanizpur, the average per acre profit for Khanizpur farmers was estimated to be INR 14,579 vis-à-vis a loss of INR 2,831 in the previous wet season. Most of the rise in net income can be attributed to higher yield, which increased from 1.5 to 2.4 tons per acre because of good-quality seeds and the adoption of improved practices such as transplanting of young seedlings and timely application of fertilizer of the right dosage. The $p$ value of close to zero for the two-sample t-test rejects the null hypothesis of no difference in income between the baseline and SFLF season. Although the average per acre net income of all participating farmers in Taraboisasan and Khanizpur increased because of the SFLF farming system, there were differences in the increase in net income of farmers of different sizes. The percentage increase in net income of the farmers with landholding up to 0.5 acre was found to be the highest with 70 percent increase whereas the net income of largest farmers in the group with more than 2.5 acres landholding increased by 23 percent (Fig. 4). The large proportion of farmers which fall under the middle 
Table 2 Real Cost and Returns, Khanizpur (in 2016 price)

\begin{tabular}{|c|c|c|}
\hline Item & $\begin{array}{l}\text { Wet (Kharif) } 2016 \\
\text { Baseline }\end{array}$ & $\begin{array}{l}\text { Wet (Kharif) } 2017 \\
\text { SFLF }\end{array}$ \\
\hline Yield (tons/acre) & 1.5 & 2.4 \\
\hline Price (INR/quintal) & 1107 & 1324 \\
\hline Gross income (INR/acre) & 16,605 & 31,773 \\
\hline \multicolumn{3}{|l|}{ COST and Return per Acre } \\
\hline Seed & 513 & 435 \\
\hline Seed treatment & 0 & 0 \\
\hline Nursery bed preparation & 390 & 310 \\
\hline Land preparation & 2029 & 1670 \\
\hline Irrigation & 0 & 0 \\
\hline Crop establishment & 5150 & 4629 \\
\hline Gap filling & 0 & 0 \\
\hline Manual + chemical weeding & 2386 & 1869 \\
\hline Fertilizer application & 2616 & 2226 \\
\hline Pesticide & 559 & 579 \\
\hline Harvesting (manual) & 4386 & 4155 \\
\hline Threshing and winnowing & 1100 & 993 \\
\hline Storage & 289 & 329 \\
\hline Total Cost & 19,418 & 17,194 \\
\hline Net Return & -2831 & 14,579 \\
\hline $\begin{array}{l}\text { T statistics } \\
\text { (p value) }\end{array}$ & & $\begin{array}{l}38.02 \\
(<0.00001)\end{array}$ \\
\hline
\end{tabular}

three groups of 0.5 to 2 acres, the net income increased from 46 to 60 percent.

\section{Policy reforms needed for faster scaling up of the SFLF model}

Overall, the analysis of the SFLF pilot in two locations for multiple seasons suggests that this is appropriate for Indian agriculture where the majority of the farmers are small and marginal in size. However, several policy and institutional reforms could be introduced to accelerate the adoption and scaling up of land consolidation models such as SFLF in the country.

First and foremost, the participating women farmers from Khanizpur had difficulty with the landowners in agreeing to the terms and conditions of SFLF group farming. Since tenancy is not recognized by the government system, the informal tenancy system has been on the rise because of rapid rural outmigration, which forces landlords to give land to tenants with a verbal agreement. In 2013, nearly 21 million households cultivated approximately 11 million hectares of land on an informal lease basis, according to the 70th round of the National Sample Survey Organization (NSSO). In Khanizpur, the landowners were not comfortable with the concept of the SFLF type of group farming that will empower farmers to raise their voice against any form of injustice and unfair treatment.

But the good news is that the legalization of the tenancy act has been proposed by Niti Ayog (formerly known as the Indian Planning Commission), which will involve the formalization of land leasing agreements between landlords and tenants. This will remove the fear on the part of the landlords of losing their land to the tenants. At the same time, tenants will be recognized as the operators of land and can apply for an institutional loan, insurance, and disaster relief. Once this happens, tenants will be more interested in participating in a land consolidation model such as SFLF to improve efficiency and decrease cost.

Second, the current marketing system (the Agricultural Produce Market Committee: APMC), which prohibits farmers from selling their crops directly to traders/supermarkets/retailers, acted as a hinderance for participating SFLF farmers to adequately be compensated for their higher quality produce, which is a hallmark of SFLF group farming through good-quality seed, no varietal mix, and improved production practices. The deregulation of the
Fig. 4 Net Income Increase by Landholding Size.

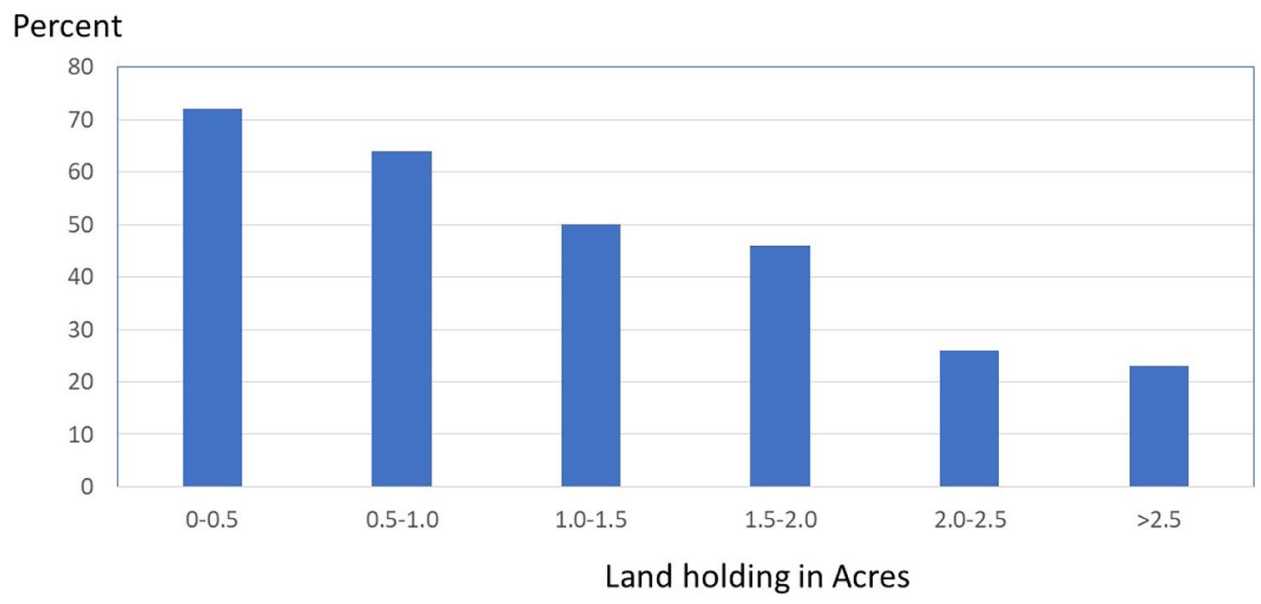


APMC will allow the development of private markets and the direct trade of agricultural products from farmers to consumers. In this deregulated market environment, SFLF types of group farming will be very attractive because of the premium paid for high-quality produce.

Third, the SFLF pilot in the wet season in Khanizpur took place where the women tenant farmers were exposed to flood and drought and did not want to invest more in the form of certified seeds and recommended fertilizer application because of the fear of losing their crop. The availability of yield or weather index insurance at an affordable premium could provide some relief to the farmers in terms of being able to invest in good-quality seeds and improved production practices.

Fourth, there was a huge problem for many farmers and sharecroppers at both sites to make timely payments for bulk input purchases. In some cases, other large participating farmers helped their fellow farmers by lending money for the input purchases. The success of a collective action model such as SFLF requires timely payment by participating farmers for seeds, fertilizer, and machinery rental from service providers to be able to obtain a price discount on bulk purchases. The overall availability and access to shortterm credit to cover operational costs and long-term loans for land improvement and farm machinery purchases will encourage farmers to participate in group farming.

Finally, it was observed that the SFLF farming model requires significant handholding and facilitation in the first couple of seasons to make it successful. In the pilot exercise, a full-time field technician was employed to work with the farmers throughout the season to make it successful. But the good news is that, once farmers realized the benefits, the model was highly sustainable. In the Taraboisasan pilot, the number of farmers increased significantly and continued in the third season without any handholding. The government should retool extension services to support the spread of innovative farming models such as SFLF. Unlike the Green Revolution era extension service that focused on technology transfer in a supply-pushed food value chain, the new system should focus on business skills, facilitation, backward and forward linkages, and other skills needed by farmers in a demand-driven food system. Apart from the government extension system, the role of other actors, including the private sector, should be actively encouraged.

\section{Concluding remarks}

The rising labor scarcity and rapidly rising wage rates have made matters worse for millions of small and marginal farmers in India who are already at a disadvantage because of diseconomies of scale and the lack of bargaining power in input and output markets. In this study, an innovative bottom-up informal collective production model was piloted to examine its benefits for small landholding farmers from economies of scale and bargaining power in input and output markets. The SFLF pilot model was found to be a very attractive option for small and marginal farmers who can significantly increase their income by harmonizing and synchronizing selected operations to achieve scale and gain bargaining power in input purchases and output sales. The net income of participating farmers more than doubled in both pilot locations. Apart from monetary benefits, the farmers also saved time in many joint activities, including input (seed and fertilizer) purchases, paddy sales, and nursery bed management. Other important benefits of the harmonization and synchronization of farming operations include social harmony and sustainability of the farming system. Farmers used to grow different varieties at different times, leading to different irrigation schedules.

When farmers practiced an individual mode of farming and grew different varieties, each field needed water at different times and the farmers faced difficulty in coordinating effective irrigation. The situation became complex when one plot needed irrigation and the adjacent plot belonging to another farmer had mature standing crops. This created problems among the farmers when water flowed into another's field when water was not needed there. The SFLF farming system eliminated those problems since crops were transplanted at the same time and the irrigation water flow from one field to another was appreciated by the farmers in the downstream. This increased water-use efficiency and improved the sustainability of the farming system. This also led to improved relationships among farmers. In one instance, a participating farmer broke his leg during transplanting time and, since all the farmers were required to do transplanting at the same synchronized time, others pitched in to complete the transplanting for the farmer with the broken leg.

The sustainability of this model was also witnessed when more farmers in Taraboisasan decided to join the group after witnessing the yield growth, profit, and benefits of the participating farmers. The number of farmers in the 2017-18 wet season increased from 54 to 77, with 171 acres of land pledged to the SFLF model. In the third season (2017-18 dry), 55 farmers from the village came together, again putting together 102 acres of land in three patches to practice the model. Several policy measures can be undertaken to accelerate the spread of the SFLF collective action model. These include the legalization of tenant farming to encourage tenant farmers to participate in collective actions, deregulation of the APMC act to directly connect farmers with supermarkets and other buyers, providing availability of yield and weather index insurance products to decrease farmers' production risk, 
providing credit availability, and strengthening the extension system to provide handholding necessary for the first couple of seasons.

\section{Declarations}

Conflict of interest The authors declare that they have no conflict of interest.

Open Access This article is licensed under a Creative Commons Attribution 4.0 International License, which permits use, sharing, adaptation, distribution and reproduction in any medium or format, as long as you give appropriate credit to the original author(s) and the source, provide a link to the Creative Commons licence, and indicate if changes were made. The images or other third party material in this article are included in the article's Creative Commons licence, unless indicated otherwise in a credit line to the material. If material is not included in the article's Creative Commons licence and your intended use is not permitted by statutory regulation or exceeds the permitted use, you will need to obtain permission directly from the copyright holder. To view a copy of this licence, visit http://creativecommons.org/licenses/by/4.0/.

\section{References}

Ali, N. (2018). Checking rural migration through enhancing farmers income and improving their living conditions. Indian Farming, 68(01), 7-11.

Al-Hassan, R. M., Sarpong, D. B., \& Mensah-Bonsu, A. (2006). Linking Smallholders to Markets, Ghana Strategy Support Program Background Paper No. GSSP 0001. Department of Agricultural Economics and Agribusiness, University of Ghana: Legon.

Ba, H. A., de Mey, Y., Thoron, S., \& Demont, M. (2019). Inclusiveness of contract farming along the vertical coordination continuum: Evidence from the Vietnamese rice sector. Land Use Policy, 87.

Bardhan, P. (1989). The Economic Theory of Agrarian Institutions. Oxford University Press.

Bishnoi, R., \& Kumari, S. (2020). Challenges Faced by FPOs \& Strategies to Overcome: A Review. International Journal of Advances in Agricultural Science and Technology (IJAAST), 7(6), 25-33.

Chambers, R. (1994). Participatory Rural Appraisal (PRA): Challenges. Potentials and Paradigm, World Development, 22(10), 1437-1454.

Chand, R. (2017). Doubling Farmers' Income: Rationale, Strategy, Prospects and Action Plan, NITI Policy Paper No. 1. National Institute for Transforming India.

Clay, J. (2004). World Agriculture and the Environment: A Commodityby-Commodity Guide to Impacts and Practices. Island Press.

Creswell, J. W., \& Plano Clark, V. L. (2011). Designing and Conducting Mixed Methods Research (p. 457). Sage.

Dang, H. (2016). Promoting cooperation, develop large field models in Mekong River Delta. Communist Party of Vietnam Online Newspaper.

Deshingkar, P. (2010). Migration, remote rural areas and chronic poverty in India, ODI Working Paper 323 and CPRC Working Paper 163. Overseas Development Institute.

FICCI (Federation of Indian Chambers of Commerce \& Industry). (2015a). Labour in Indian Agriculture: A Growing Challenge. KPMG. Available at: https://ficci.in/spdocument/20550/FICCIagri-Reportpercent2009-03-2015.pdf
FICCI (Federation of Indian Chambers of Commerce \& Industry). (2015b). Transforming Agriculture Through Mechanization - A Knowledge Paper on Indian Farm Equipment Sector, Grant Thornton.

Gillis, A., \& Jackson, W. (2002). Research for Nurses: Methods and Interpretations. F.A. Davis Co.: Philadelphia.

GOI (Government of India). (2019). Agriculture Census Report. Ministry of Agriculture.

Gulati, A., \& Saini, S. (2016). From Plate to Plough: Raising Farmers' Income by 2020. Indian Express. Available at: https://indianexpress.com/article/opinion/columns/fromplate-to-plough-raising-farmers-income-by-2022-agriculturenarendra-modi-pradhan-mantri-fasal-bima-yojana/

ILO (International Labor Organization). (2018). India Wage Report: Wage policies for decent work and inclusive growth. Available at: https://www.ilo.org/newdelhi/whatwedo/publications/WCMS_ 638305/lang--en/index.htm

Mehta, C. R., Chandel, N. S., Jena, P. C., \& Jha, A. (2019). Indian Agriculture Counting on Farm Mechanization, Agricultural Mechanization in Asia, Africa \& Latin. America, 50(1), 84-89.

Mohanty, S., Mohapatra, B., Baruah, S., \& Veettil, P. (2018). Piloting the Vietnamese "Small Farmers, Large Field" scheme in eastern India. Rice Today, International Rice Research Institute.

Morgan, D. L. (2014). Integrating Qualitative and Quantitative Methods: A Pragmatic Approach. Sage.

Murthy, D. S., Gajanana, T. M., Sudha, M., \& Dakshinamoorthy, V. (2007). Marketing Losses and Their Impacts on Marketing Margins: A Case Study of Banana in Karnataka. Agricultural Economics Research Review, 20(1), 47-60.

NABARD. (2019). Farmers Producer Organizations: Frequently asked questions. National Bank for Rural Development, National Paper - PLP 2019-20. Mumbai.

Narain, N., \& Bhal, K. (2016). The Social Change Professional: The context and roles of the social change professional viewed through the lens of professional client relationships, Practicing Social Change. The NTL Institute for Applied Behavioral Science.

Rossman, G. B., \& Wilson, B. L. (1985). Numbers and words: Combining quantitative and qualitative methods in a single large-scale evaluation study. Evaluation Review, 9(5), 627-643.

Singh, S. (2018). Doubling Farmers' Incomes: Mechanisms and Challenges. Economic \& Political Weekly, 53(7).

Singh, S., Singh, R., \& Singh, S. (2014). Farm Power Availability on Indian Farms. Agricultural Engineering Today, 39(1), 48-52.

Schoonenboom, J., \& Johnson, R. B. (2017). How to Construct a Mixed Methods Research Design. Köln Z Soziol, 69(2), 107-131.

Tashakkori, A., \& Teddlie, C. (1998). Mixed Methodology: Combining Qualitative and Quantitative Approaches, Applied Social Research Methods Series, 46. Sage Publications.

Thang, T. C., Khoi, D. K., Thiep, D. H., Lan, V. T., Tinh, T. V., \& Pede, V. O. (2017). Assessing the Potential of Climate Smart Agriculture in Large Rice Field Models in Vietnam, CCAFS Working Paper No. 211. CGIAR Research Program on Climate Change, Agriculture and Food Security (CCAFS): Wageningen, the Netherlands. Available online at www.ccafs.cgiar.org

Timmer, C. P. (2002). Agriculture and economic development. Handbook of Agricultural Economics, 2, 1487-1546.

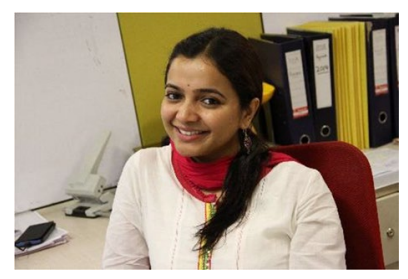

Sampriti Baruah Dr. Sampriti Baruah is presently the Project Coordinator for the India, Vietnam and the Philippines Research Units International Potato Center (CIP) in Asia. She holds her PhD in Development Studies from the College of 
Public Affairs of the University of the Philippines Los Baños (UPLB) with her dissertation on "Small Farmers, Large Field Model: A Participatory Research to Improve the Livelihood of Small Farmers in India through Synchronized Collective Actions". Also, she earned a M.A. in Social Development and Sustainable Livelihood from the University of Reading, United Kingdom and a M.A in Social Work from Tata Institute of Social Science, India. She brings many years of experience as Associate Scientist for the Social Sciences Division and as $\mathrm{PhD}$ Scholar with the Agri-Food policy platform for The International Rice Research Institute (IRRI). Later she joined the International Potato (CIP) as Development and Innovation Specialist in Delhi, India.

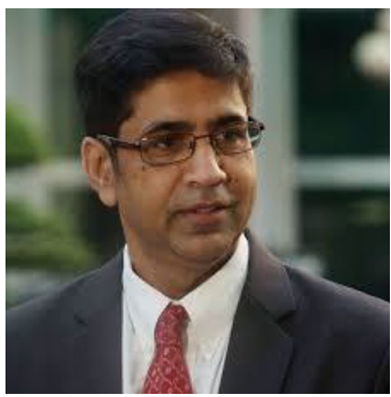

Samarendu Mohanty Dr. Samarendu Mohanty is the regional director for the International Potato Center (CIP) in Asia. He provides programmatic oversight for research and development portfolio; provides leadership in regional operational systems; and plays representational role for CIP in the region, with a focus on India, Bangladesh, Vietnam, Indonesia and the Philippines. He holds a Ph.D. in Agricultural Economics from University of Nebraska-Lincoln, a M.S. in Agricultural Economics from University of Nebraska-Lincoln and a B.Sc. from University of Agricultural Sciences in Bangalore, India. He brings over 20 years of experience with skills in Research Management, Fund Raising, Commodity Markets, Research Funding, Asset Management, Policy and Trade Analysis. He joined CIP after working as Principal Scientist at the International Rice Research Institute - IRRI in Philippines and previously as
Head and Senior Economist for the Social Sciences Division in IRRI since 2008. Previously, he also worked as Associate Professor and Associate Director for Cotton Economics Research Institute at Texas Tech University and scientist at Food and Agricultural Policy Research Institute at Iowa State University.

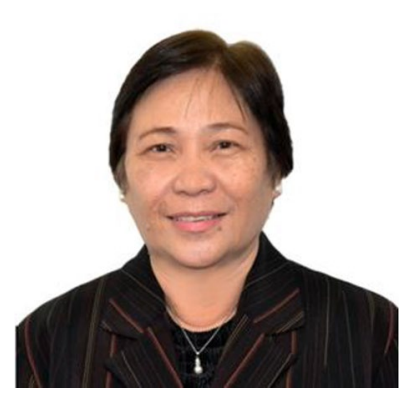

Agnes C. Rola Dr. Agnes C. Rola is a professor emeritus and a former dean at the University of the Philippines Los Banos (UPLB) College of Public Affairs and Development. Dr. Rola is recognized for her body of work in integrative thinking, particularly in understanding the link between and among agriculture, the environment, and sustainable community development. She was awarded Outstanding Senior

Faculty Researcher for Social Sciences for her distinctive contribution in the field of agriculture, particularly in terms of the economic, policy, and institutional aspects of externalities caused by pesticide use and intensive upland cultivation. The results of her studies not only contributed to the methodological development of sustainable agriculture and natural resources management but also greatly influenced both national and local policies. Dr. Rola obtained her PhD degree in Agricultural Economics from the University of Wisconsin-Madison, her MS in Agricultural Economics from UPLB, and her BS in Statistics degree from the University of the Philippines Diliman. Dr. Rola was a recipient of the UP-Productivity Award as UP Scientist II (2008-2010) and was conferred the rank and title of Academician by the National Academy of Science and Technology in July 2011. 